\title{
Razumevanje in opredeljevanje čustvenih in vedenjskih težav in/ali motenj v polju vzgojnih zavodov
}

\author{
Mateja Marovič \\ OŠ Veržej - enota DOM, \\ Univerza na Primorskem, Pedagoška fakulteta
}

\section{Uvod}

Schultheiss že leta 1974 (v Metljak, Kobolt in Potočnik, 2010, str. 91) postavi še danes veljavno tezo: »Termini na tem področju odslikavajo družbeno razumevanje otrok in vzgoje, značilno za neko zgodovinsko dobo. «

$\mathrm{V}$ toku zgodovine je tako razumevanje populacije - drugačne od zaželenih družbeno pogojenih norm določenega časa, kot tudi z njo povezano izrazoslovje - zaznamovano s prevladujočimi paradigmami takratnega časa. Opredelitve se sicer skozi čas in prostor spreminjajo (Razpotnik, 2011). Izraze: zanemarjena, težje vzgojljiva, ubožna mladina, kot tudi izraz motnje vedenja in osebnosti nadomestijo izrazi: otroci/mladostniki s čustvenimi in vedenjskimi težavami/motnjami, otroci s težavami v socialni integraciji, moteči otroci, otroci $z$ izstopajočim vedenjem idr., vendar pa si tudi glede slednjih avtorji danes niso enotni. Zdi se, da so poimenovanja kot tudi že obstoječe klasifikacije »dekontekstualizirana in brez prave refleksije ter izražajo prej ostanke nekih prejšnjih diskurzov /.../ ter inercijo različnih ustanov in paradigem, da bi ohranile svoja polja delovanja ne glede na spreminjajoče se družbene razmere.« (str. 103). Prizadevanja socialnopedagoške stroke, »da bi se poimenovanja, ki se v določenem času in prostoru uveljavijo za označevanje posameznikov, katerih vedenje je predvsem

1 Prav tako termini, ki jih za opredeljevanje določene populacije uporabljamo, odsevajo kontekst, "v katerem opazujemo ali izkušamo posamezna vedenja in predsodke, ki jih do njih gojimo« (Leone, v Kosmač, 2007, str. 386). 
znotraj vzgojno-izobraževalnih kontekstov znano kot moteče, reflektirala, spreminjala in širše odražala kompleksno problematiko, v kateri se določeno vedenje pojavlja« (str. 105), ter vse glasnejši apeli, ki v zadnjih letih izhajajo iz neposrednega dela strokovnih delavcev ter njihovega zaznavanja značilnosti omenjene populacije v vzgojnih zavodih (v nadaljevanju: VZ), pa ostajajo »Z vidika zakonodajalcev ter drugih strok preslišani« (str. 105).

Terminološko zmedo ${ }^{2} \mathrm{v}$ zvezi s poimenovanjem populacije nameščene v VZ je tako zaznati v številnih pravno veljavnih dokumentih (Bela knjiga o vzgoji in izobraževanju v Republiki Sloveniji (v nadaljevanju: BKVIZ), 2011; Zakon o usmerjanju otrok s posebnimi potrebami (v nadaljevanju: ZUOPP-1), 2011 idr.) kot tudi v okviru socialnopedagoške doktrine razumevanja omenjenega opredeljevanja, ki je s populacijo s čustvenimi in vedenjskimi težavami in/ali motnjami (v nadaljevanju: ČVT/M) najbolj neposredno povezana (Kobal Tomc idr., 2011; Kobolt, 2011; Krajnčan, 2010; Marovič, 2017; Myschker, 2009 idr.).

Čeprav je terminologija poimenovanja določenega dela populacije $\mathrm{v}$ večini (sicer) domena stroke, ki se $\mathrm{z}$ njo profesionalno ali znanstveno ukvarja, pa tudi znotraj ožje socialnopedagoške doktrine, ki je z opredeljevanjem omenjene populacije najbolj usodno povezana, teorija in praksa velikokrat ne zavzemata istih stališč.

Enotnih kriterijev, ki bi hkrati zajemali vse specifike znotraj različnih raziskovalnih področij opredeljevanja ČVT/M, tako skorajda ni mogoče izoblikovati. Zato še vedno, kot že pred slabimi tridesetimi leti, ostaja nesporno dejstvo, da so opredeljevanje, obravnava in tudi razumevanje disocialnosti otrok in mladostnikov ter z njimi povezana terminologija kot bo razvidno v nadaljevanju - nekatera izmed tistih področij, »ki jim tudi današnja razvitost različnih strok ni kos v taki meri, kot bi si to želeli.« (Bečaj, 1987, str. 9).

2 Tudi Myschker (2009) zapiše, da sta analiza pojma in terminološka določitev le-tega - gledano z internacionalnega vidika - nedoločena. Stališče opredeljevanja ČVT/M ostaja (tako kot prej) enako, kot je pred časom zapisal priznani ameriški socialni pedagog Kaufmann (v Myschker, 2009): »Dejstvo je, da je terminologija na tem področju pogosto tako zavajajoča, kot so otroci in mladostniki, katerim oznake opredelitev pripisujemo.« Zato ne preseneča, da se, ko govorimo o ČVT/M, »srečujemo z izrazi, ki nakazujejo velike razlike v pristopih in v razumevanju.« (Metljak idr., 2010, str. 88). 


\section{Pregled nekaterih opredelitev ${ }^{3}$ čustvenih in vedenjskih težav in/ali motenj}

Značilnosti težav in odklonov $\mathrm{v}$ opredeljevanju vedenja otrok in mladostnikov v polju razumevanja ČVT/M ter poskusi definiranja le-teh se v nadaljevanju izražajo v ugotovitvah različnih avtorjev, pri katerih iz svoje profesionalne usmerjenosti izhajajo. Definicije, ki sledijo, omogočajo poglobljeno razumevanje otrok/mladostnikov s ČVT/M in so več ali manj prisotne tudi $\mathrm{v}$ praksi delovanja slovenskih $\mathrm{VZ}$, hkrati pa nakazujejo na protislovnost pojmovanj ter kompleksnost problematike, ki se (kot že izpostavljeno) razprostira na kontinuumu terminološke in definicijske nedorečenosti omenjene populacije.

Čustvene, vedenjske in socialne težave, tako D. Zorc Maver (2010, str. 24), lahko razumemo kot "nezadovoljivo ujemanje med osebo in okoljem, ki prizadene osebo in/ali njeno okolje«. Lahko pa, tako Š. Byrne (2010, str. 32), gledamo nanje »kot na socialni konstrukt, saj je definiranje vedenja kot težavnega odvisno od socialnih in kulturnih pričakovanj, prepričanj in kontekstualnih faktorjev.« (prim. Kobolt, 2011; Kosmač, 2007; Myschker, 2009 idr.). So tesno povezane $s$ »socialnim kontekstom, na katerega se sleherni človek odziva na osnovi značilnosti svoje percepcije socialnega konteksta, svojih preteklih izkušenj in sedanjih pričakovanj, doživljanja lastne socialne umeščenosti in socialnega položaja, ki ga zavzema v različnih socialnih okoljih.« (Metljak idr., 2010, str. 89).

Po Bronfenbrennerjevem ekološkem modelu (Svetin Jakopič, 2005) sta tako posameznikov razvoj, kot posledično tudi nastanek in razvoj psihosocialnih (vedenjskih) motenj, odvisna od celotnega življenjskega sistema, ki ga tvorijo: otrok sam; mikrosistemi (družina, prijatelji, šola ipd.); mezosistemi (interakcije med mikrosistemi); ekosistemi (lokalne šolske oblasti, so-

3 Opredelitve, objavljene pred letom 2007, v večini izhajajo iz zakonsko opredeljenega termina, aktualnega za takratno obdobje, in sicer motnje vedenja in osebnosti. Termine puščamo $\mathrm{v}$ prvotnem izrazoslovju predvsem zaradi razvidnosti, da se definicije ČVT/M kljub spremembi terminologije niso spremenile, temveč lete ostajajo $\mathrm{z}$ dopolnitvami ter ugotovitvami posameznih avtorjev $\mathrm{v}$ svojem bistvu identične slednjim. Tako še vedno ohranjajo iste razlagalno vsebovane komponente, kljub temu da so se krovni termini preimenovali. Če poenostavimo: tisto, kar je še pred časom veljalo za opredelitve populacije z motnjami vedenja in osebnosti, velja danes (z rahlimi posodobitvami in spremembami izrazoslovja) za opredelitve populacije s čustvenimi in vedenjskimi težavami in/ali motnjami. Razlika je tako opazna le v izrazoslovju, ki nakazuje premik k manj stigmatizirajočemu diskurzu razumevanja omenjene populacije, niso pa se, kot že Opara idr. (2010), spremenili kriteriji. 
cialna politika ipd.); makrosistemi (ideologija, vrednote, kultura, vedenjski vzorci naroda, socialnega razreda, etnične skupine ipd.).

Krajnčan in Škoflek (200o) vedenjske in osebnostne motnje razumeta kot pojavnosti, ki so si od vseh razvojnih motenj - kot so motnje v duševnem razvoju, gluhota, govorne motnje, slepota in gibalna oviranost - najmanj podobne oziroma enotne. Pravita, da imajo le-te, bolj kot vse razvojne motnje, skoraj vsaka

"svoj specifičen splet vzrokov za nastanek in patogeni razvoj, pa tudi verjetnost oziroma intenzivnost njihovega pojavljanja ni povsem predvidljiva, saj je tudi bolj kot vse ostale razvojne motnje odvisna od otrokovega/mladostnikovega trenutnega psihofizičnega stanja, senzibilnosti trenutnega okolja za odklonsko vedenje ter interaktivnih spodbud (med okoliščinami in otrokom/mladostnikom).« (str. 168)

Bečaj (2003) zapiše, da so motnje vedenja in osebnosti posebna oblika disocialnosti, povezane $\mathrm{z}$ motenim čustvenim razvojem. Ugotavlja, da »pri takem otroku oz. mladostniku lahko ugotovimo značilno disfunkcionalnost na vseh življenjskih področjih, kar je posledica specifične organiziranosti osebnostne strukture. Ne gre torej za to, da otrok s svojim disocialnim ravnanjem prihaja $\mathrm{v}$ konflikte $\mathrm{z}$ okoljem le $\mathrm{v}$ določenem okviru ali le na določenih področjih in situacijah, medtem ko je drugod normalno prilagojen« (str. 16), temveč v konflikte prihaja povsod. ${ }^{4}$

Redl in Wineman (1984) motnje vedenja ter čustvovanja otrok/mladostnikov - pri čemer izhajata iz psihoanalitične teorije - razlagata preko slabe razvitosti otrokovega/mladostnikovega »kontrolnega sistema", in sicer kot motnjo ega in nerazvitost superega ${ }^{5}$.

4 Temeljne posebnosti omenjene populacije, kot nadaljuje avtor, se izražajo v: nizki frustracijski toleranci, slabem nadzoru nad svojim vedenjem, nestrukturiranosti, kratkotrajni motivaciji, težavah na področju čustvovanja, težavah na področju socialnega vedenja, ki so povezane zlasti s strahom pred zavrnitvijo, negotovosti vase, strahu pred rivalitetnimi situacijami in neuspehom ipd. (Bečaj, 2003). Kot osrednjo težavo Bečaj izpostavi slabo samopodobo, za katero pravi, da je z zunanjim vedenjem uspešno prekrita. Tak otrok navzven deluje kot predrzen in agresiven, zaradi česar okolje njegove negativne samopodobe praviloma ne prepozna (Bečaj, 2003; prim. Skalar, 2003; Svetin Jakopič, 2005).

5 Superego, ki pomeni več ali manj isto kot vest, nas spominja na vrednote, ki so del vsakdanjega življenja. Za ego predpostavljamo, da nas bo vodil v skladu z realnostjo. V vsaki situaciji deluje več delov osebnosti, pri čemer je naloga ega skrb za koordinacijo, kar pomeni, da odloča, koliko naj na osebnost vplivajo zahteve impulzivnega sistema, koliko zahteve zunanje realnosti ter koliko lastna zavest. Uravnoteženo 
Skalar (2003) meni, da so otroci s čustvenimi in vedenjskimi težavami, ki jih enači z otroki z motnjami vedenja in osebnosti ter otroki s težavami v socialni integraciji, »otroci, ki s svojim vedenjem ogrožajo same sebe, svoje življenje in zdravje, svojo osebnostno in socialno integriteto, in pa otroci, katerih vedenje je ogrožajoče za socialno okolje, ker je uperjeno proti pravilom, vrednostim in vrednotam, tudi proti veljavnim moralnim normam in zakonom « (str. 9). Pravi, da v »kategorijo s čustvenimi in vedenjskimi težavami uvrščamo samo otroke, pri katerih predstavljajo neustrezni vedenjski vzorec trajnejša in hujša odstopanja od vedenjskih vzorcev, značilnih za otroka v določenem časovnem obdobju« (str. 9; prim. ZUOPP-1, 2011; Mednarodna klasifikacija bolezni (v nadaljevanju: MKB-10), 2005).

Metljak idr. (2010) v prispevku z naslovom Narava vedenjskih, čustvenih in socialnih težav se izmika definicijam, na temeljih izčrpnega pregleda predvsem tuje (anglosaške) literature, kot najbolj smiselna termina za poimenovanje čustvenih in vedenjskih težav in razlago le-teh izpostavijo: ${ }^{6}$

- socialnointegracijske težave, s katerimi poudarijo »težavo, ki jo ima posameznik (saj ne zanika individualne ravni ali dimenzije), in vpelje socialno, družbeno, skupinsko, okoljsko raven, ki je z nastajanjem in vzdrževanjem tovrstnih težav usodno povezana" (Metljak, 2010, str. 89);

- čustvene, vedenjske in socialne težave/motnje - $\mathrm{z}$ izrazom opozorijo, »da se težave pojavijo na enem, dveh ali vsaj treh področjih, najpogosteje pa so soodvisne in druga drugo vzdržujejo« (Metljak, 2010, str. 89).

Če izhajamo iz aktualne šolske zakonodaje - natančneje iz ZUOPP-1 (2011), s katerim se je skupno s sprejetjem univerzalnega naziva otroci s posebnimi potrebami (v nadaljevanju: OPP) začela spreminjati zakonska regulativa za populacijo OPP - opredeljuje le-ta kot eno izmed kategorij otroke šcustvenimi in vedenjskimi motnjami. Omenjeno kategorijo poimenuje:

"Otroci s čustvenimi in vedenjskimi motnjami so otroci $z$ disocialnim vedenjem, ki je intenzivno, ponavljajoče se in trajnejše ter se

osebnost torej predstavlja pravilna koordinacija vseh zgoraj omenjenih sistemov, za katero skrbi ego. Delinkventni ego pa daje prednost impulzivnosti ali superegu.

6 V podpoglavju Spekter opredelitev čustvenih in vedenjskih težav/motenj zgoraj navedeni avtorji uporabljajo termin čustvene, vedenjske težave in socialne težave, "vendar z zavedanjem, da je to izraz posplošitve, da ostaja kategorialna nalepka, ki ne odraža enkratnosti in posameznih, lahko zelo raznolikih značilnosti tako posameznika kot njegove socialne umeščenosti.« (Metljak idr., 2010, str. 93) 
kaže z neuspešno socialno integracijo. Otrokovo disocialno vedenje je lahko zunanje ali notranje pogojeno in se kaže s simptomi, kot so npr. agresivno vedenje, uživanje alkohola in mamil, uničevanje tuje lastnine, pobegi od doma, čustvene motnje. Otrok je lahko prepoznan kot otrok s čustvenimi in vedenjskimi motnjami le $v$ primerih, ko dosedanje delo šolske svetovalne službe in drugih strokovnih delavcev $z$ otroki, socialno skupino in družino ni vodilo do zmanjšanja opisanih težav. Kljub temu da se nekatera omenjena stanja in vzorci vedenja kažejo že zgodaj v otroštvu, se diagnoza osebnostne motnje ne postavlja, vse dokler ni zaključen otrokov osebnostni razvoj.« (ZUOPP-1, 2011).

MKB-10 (2005) v poglavju Vedenjske in čustvene motnje, ki se začnejo navadno v otroštvu in adolescenci (F9o-F98) "motnje vedenja " okarakterizira kot: »Motnje, za katere je značilen ponavljajoč se in trajen vzorec disocialnega, agresivnega ali predrznega vedenja. Takšno vedenje lahko velja za hujše kršitve starosti ustreznih družbenih pričakovanj; bile naj bi torej hujše kot običajna otroška objestnost ali adolescentna upornost in naj bi imele značaj trajnega vzorca vedenja (6 mesecev ali dalj).« (str. 379)

Bennett (v Metljak idr., 2010, str. 97) ugotavlja, da je termin »vedenjska motnja $\mathrm{v}$ "zgodovini opredeljen s celo paleto besed, ki opisujejo karakteristike asocialnega vedenja; delinkventno, neprilagojeno, deviantno, hiperaktivno, nevodljivo in agresivno vedenje.«

Myschker (2009) pri opredelitvi "vedenjske motnje« izhaja iz prilagodljivega ${ }^{8}$ (adaptive) in neprilagodljivega ${ }^{9}$ (maladaptive) vedenja. Upoštevajoč navedene značilnosti obeh oblik vedenja avtor vedenjsko motnjo ${ }^{10}$ oprede-

$7 \quad \mathrm{~V}$ nadaljevanju klasifikacija - kot primere vzorcev vedenja, na katerih temelji diagnoza - izpostavi, da le-ti »vključujejo pretirano borbenost in ustrahovanje, krutost do drugih ljudi ali živali, hudo uničevalno težnjo do lastnine, požigalništvo, krajo, nagnjenje k laganju, 'špricanje' šole in pobege od doma, nenavadno pogosto in hudo togoto ter neubogljivost" (MKB-10, 2005). Za diagnozo "motnje vedenja" po klasifikaciji zadostuje katera koli od oblik naštetega vedenja, če je izrazita.

Prilagodljivo vedenje je rezultat ustreznega zaznavanja, predelave, ovrednotenja in aktivacije. Omogoča spremembo neprimernega oz. motečega vedenja v primerno. Neprilagodljivo vedenje temelji na disfunkcionalnem sprejemanju, čustvih ter kogniciji in se manifestira v neprimernih ter socialno neustreznih oblikah premagovanja življenjskih ovir.

10 Za vedenjsko motnjo Myschker pravi, da jo je brez posebne strokovne oz. pedagoško terapevtske obravnave nemogoče zadovoljivo odpraviti. Definira jo kot fenomenološko nadrejeni pojem, kateremu se - zaradi specifičnega gledišča, aktualnost in razumevanja fenomena posameznih strok - v različnih znanstvenih disciplinah pri- 
li kot: »odstopajoče, neprilagodljivo, miljejsko povzročeno vedenje, pogojeno s časovnimi in kulturnimi pričakovanj določene družbe, ki nastane zaradi večdimenzionalnosti, pogostosti in težavnosti razvojnih, učnih ter delovnih sposobnosti, kot tudi zaradi interakcijskega dogajanja v okolju « (str. 49).

Kot Myschker definira fenomenološko nadrejeni pojem »vedenjsko motnjo«, pa Mars in Cooper (v Metljak idr., 2010, str. 95) kot krovni termin opredeljujeta »čustvene in vedenjske težave«. Le-ta, tako avtorja, »vsebuje širok spekter težav in potreb, skupaj s problemi, ki se kažejo v čustveni in vedenjski obliki, in problemi, ki vsebujejo obe dimenziji, čustveno in vedenjsko.« Metljak idr. (str. 89) na podlagi navedenega pri razumevanju čustvenih in vedenjskih težav (med drugim) izhajajo iz čustvene in vedenjske dimenzije, pri čemer je lahko izrazitejša bodisi čustvena bodisi vedenjska, "obe pa nastopata skupaj in sta v medsebojni soodvisnosti."

Kobal Tomc idr. (2011) ugotavljajo, da so čustvene in vedenjske motnje izražene v različnih stopnjah, ${ }^{\text {II }}$ katerih narava je zelo kompleksna. Pravijo, da je pri njihovi opredelitvi potrebno upoštevati medsebojno učinkovanje bioloških, psiholoških, socialnih in okoljskih dejavnikov. Čustvene in vedenjske motnje delijo na:

- $\quad$ »čustvene motnje (motnje ponotranjenja, internalizirane motnje);

- vedenjske motnje (motnje pozunanjenja, eksternalizirane motnje);

- $\quad$ vedenjske motnje, za katere je značilno intenzivno, ponavljajoče in trajno antisocialno vedenje.« (Kobal Tomc idr., 2011, str. 7)

pisujejo številne in mnoštvene pojavne oblike, ki jih zaradi navedenega razume kot podrejene (str. 49-50).

11 Podobno opredelitev je zaslediti v Kriterijih za opredelitev vrste in stopnje primanjkljajev, ovir oz. motenj otrok s posebnimi potrebami (2015), ki navajajo, da se za usmeritev otrok v kategorijo Otroci s čustvenimi in vedenjskimi motnjami upoštevajo naslednji kriteriji:

- »intenziteta čustvenih odzivov in vedenja presega stopnjo pričakovanega za razvojno obdobje ali okoliščine;

- vedenje in/ali čustvovanje je nekontrolirano ali iracionalno in se kaže vsaj šest mesecev (prim. MKB- 10, 2005); motnje se pojavljajo najmanj v dveh okoljih (npr. v šoli, doma, v vrstniški skupini, širšem okolju);

- pomembno ovirajo otrokovo učinkovitost in prilagajanje na enem ali več področjih (učni uspeh, socialni odnosi, prilagajanje šolskim pravilom, skrb zase);

- otrok nima zadosti varovalnih dejavnikov v svojem primarnem in širšem socialnem okolju (odsotnost izkušenj dobre povezanosti, doživljanje odklanjanja in zavrnitev).«(str. 32) 
Iz mnoštva predstavljenih definicij - kaj ČVT/M so in kaj niso ter kateri so tisti pogoji, ki morajo biti prisotni, da lahko govorimo o tem, da otrokovo/mladostnikovo vedenje oz. čustvovanje izstopa (prim. Kobolt, 2011) - zaključujemo, da:

- $\quad$ se pod streho definicije otrok/mladostnikov s ČVT/M skrivajo zelo različni otroci (Kosmač, 2007), ki tvorijo izrazito heterogeno skupino s specifičnimi in zelo različnimi potrebami (Kobal Tomc idr., 2011);

- $\quad$ se opredelitve ČVT/M med seboj velikokrat spodbijajo in si nasprotujejo (Kobolt, 2011; Evans, Harden in Thomas, 2004; Visser, 2003; idr.), zato igra področje, pri katerem iz opredelitev izhajamo, pomembno vlogo;

- predstavljajo poskusi definiranja ${ }^{12}$ (kot že rečeno) kompleksno problematiko (prim. Myschker, 2009; Terzi, v Opara idr., 2010; Krajnčan, 2010; idr.), ki se razprostira na kontinuumu terminološke kot tudi definicijske nedorečenosti, hkrati pa se, tako Kosmač (2007, str. 387), »hote ali nehote odražajo tudi v pojmovanju in implicitnih predstavah, ki jih do te populacije gojimo«; so ČVT/M odvisne od »časovno in kulturno pogojenih norm ter pričakovanj odklonskega, napačnega vedenja, ki nastaja zaradi organskih motenj ali neprimernega okolja, večdimenzionalnosti, pogostosti in težav v razvoju, nedoseganju učnih in delovnih zahtev, pa tudi zaradi interakcijskega dogajanja v okolju « (Krajnčan, 2006, str. 47; prim. Myschker, 2009);

- $\quad$ se čustvene in vedenjske »drugačnosti«, kot že Kobolt (2011, str. 167), »razdelijo po celotnem spektru/kontinuumu - od lažjih in redkeje izraženih do težjih/bolj nenavadnih in pogosteje izraženih« (prim. Kobal Tomc idr., 2011);

- je na ČVT/M potrebno gledati z vidika dinamike nastajanja, vzdrževanja in razvoja omenjenega fenomena $v$ specifičnem raziskovalnem področju, prav tako pa ga je treba razumeti kot večdimenzionalen, multikompleksen, interakcijski sistem psihološke,

12 O spremenljivosti definicij, tako Š. Razpotnik (2011, str. 26), govori tudi »iz različnih razlogov prisotna oteženost medsebojnih primerjav in kategorialnega aparata" (prim. Opara idr., 2010), za katero menimo, da jo je, poleg že naštetih, med drugim mogoče pripisati: 1 . neustreznemu prenosu oz. prevodu tuje terminologije v slovenski strokovni prostor ter 2. kulturni neprimerljivosti šolskega vzgojno-izobraževalnega prostora zaznavanja, diagnosticiranja ter interveniranja pri omenjeni populaciji posameznih držav. 
biološke, miljejske in socialne dimenzije razvoja posameznika, ki je s tovrstnimi težavami usodno povezan.

\section{Problematičnost opredelitev, ki izhajajo iz različnih diskurzov razumevanja}

Sprememba izrazoslovja in številčna aktualna uporaba le-tega se $\mathrm{v}$ današnjem času (bolj kot kadar koli prej) izraža v mnoštvu definicij ter poimenovanj, izhajajoč iz različnih sfer vzgojno-izobraževalnega aparata, ki laiku (tudi strokovnjaku) na omenjenem področju ne ponujajo jasnosti, temveč prej bariero nekonsistentnosti in zmede, ki posledično botruje tako zaznavanju, diagnosticiranju, nameščanju kot tudi obravnavi omenjene populacije v njim ustrezne programe pomoči.

Avtorjev, tako tujih kot domačih (npr. Kobolt, Metljak in Potočnik, 2008; Kosmač, 2007; Myschker, 2009; Razpotnik, 2011; idr.), ki izhajajoč iz različnih zornih kotov raziskovanja opozarjajo na problematičnost opredelitev ČVT/M - v polju razumevanja le-teh -, ne manjka. Nedorečenosti se kažejo tako znotraj posameznih držav, na mednarodni ravni, kot tudi med različnimi strokami (Marovič, 2017; Opara idr., 2010; Skalar, 2003). Vrsta različno utemeljenih pristopov pa aplicira na neenotnost teorij, ki jih je zaznati v raznovrstni terminologiji, s katero se populacija, katere vedenje je $\mathrm{v}$ nasprotju s prevladujočimi normami in pričakovanji socialnega okolja, opredeljuje (npr. Kenneth, Forness in Mostert, 2004; Krajnčan, 2010; Metljak idr., 2010; Vec, 2011; idr.).

Vzroke je mogoče iskati $\mathrm{v}$ različnih diskurzih razumevanja problematike, neenotnih ter kontradiktornih poimenovanjih $\mathrm{v}$ zakonodaji, neenotnosti strok (npr. pedagogike in psihiatrije), večdimenzionalnosti, v že omenjeni različnosti strokovnih paradigem idr. ter, tako Kenneth idr. (2004), v različnih socialnih kontekstih, kjer se opredelitve pojavljajo. Prav tako jasnosti ne more biti zaradi drugačnih, včasih nasprotujočih si interpretacij dotičnega (šolskega ali zavodskega) izobraževalnega aparata, iz katerega poimenovanja ČVT/M največkrat izhajajo. Če ponazorimo: ${ }^{13}$ opredelitev vedenja, npr. težavno vedenje, ima glede na okolje, iz katerega pri opredelitvi vedenja izhajamo (težavno vedenje $\mathrm{v}$ šoli ali težavno vedenje $\mathrm{v}$ zavodu), drugačno konotacijo. Vemo namreč, da je težavno vedenje, ki izhaja iz zavodskega polja, ponavadi veliko bolj »težavno« kot vedenje, ki je kot težavno opredeljeno v šoli. S težavnim vedenjem se v šoli lahko spopa-

13 Za ponazoritev smo izbrali enega izmed v slovenski literaturi uporabljajočih se terminov za opredeljevanje populacije s ČVT/M, in sicer težavno vedenje. 
demo na različne načine. $\mathrm{V}$ najslabšem primeru, seveda po vseh predhodnih intervencijah, tudi z oddajo v VZ. Če pa bi bilo vedenje, zgolj hipotetično, kot »težavno « opredeljeno v VZ (čeprav takih opredelitev vedenja $\mathrm{v}$ praksi ne podajamo), pa smo, če že drugo ne, zelo omejeni že pri samih intervencijah. Za otroka/mladostnika že nameščenega v VZ - za katerega se smatra, da posamezniku, v okviru zavodske vzgoje ter posebne zavodske obravnave, nudi vse možne oblike pomoči -, še posebej, če gre za zavod zaprtega tipa, ostaja $\mathrm{v}$ praksi bore malo alternativ. ${ }^{14}$

V literaturi, praksi ter veljavni zakonodaji za poimenovanje iste socialne pojavnosti tako danes zasledimo več med seboj ne povsem skladnih izrazov (Kosmač, 2007). Naštejmo nekatere: čustvene in vedenjske težave/ motnje, vedenjske težave/motnje, emocionalne težave/motnje, težave v socialni integraciji/adaptaciji, vedenjska problematičnost, neprilagojeno vedenje, odklonsko/deviantno vedenje, disocialnost, asocialnost, antisocialnost, delinkventnost, prestopništvo, izstopajoče vedenje, moteče vedenje, težavno vedenje, agresivno vedenje, "acting out (nekontrolirano) vedenje, vedenjska problematičnost idr. ${ }^{\text {is }}$

Sklenemo lahko, da gre pri vseh zgoraj naštetih terminih ${ }^{16}$ za $» v e d e-$ nje, ki ne ustreza pričakovanjem okolja in je zanj tako ali drugače moteče« (Bečaj, 2003, str. 13), ter za kontinuum, kjer so na eni strani prisotne značilnosti emocionalne/čustvene dimenzije, na drugi pa značilnosti dimenzije vedenj/ravnanj (Kobolt idr., 2008).

14 Posameznika, katerega vedenje bi bilo v VZ, kot že rečeno zgolj hipotetično, opredeljeno kot »težavno«, bi sicer lahko premestili v drugo vzgojno skupino, kar pa je v praksi bolj izjema kot pravilo. Premestitev predstavlja namreč, poleg že izvršene eliminacije iz primarnega okolja, še dodaten rez v njegovem življenju, z vnovično prilagoditvijo na »nove« vzgojitelje kot tudi »nove« otroke/mladostnike, s katerimi bo v nadaljevanju bival. In nenazadnje, kot ugotavljamo v praksi, tudi »težavno« vedenje s samo premestitvijo načeloma ne izzveni.

15 Kot je razvidno iz zgoraj naštetega, se termini za označevanje ČVT/M večinoma nanašajo na simptomatiko, kar pomeni, kot že Bečaj (2003, str. 13), »da ne povedo kaj dosti ali sploh ničesar o vzrokih "motnje«, o okoliščinah, v katerih je do nje prišlo, kot tudi ničesar o njeni intenzivnosti, pač pa le to, da je nekdo s svojim vedenjem prekršil določena pravila.« (prim. Kosmač, 2007). Prav tako velja opozoriti, da so ČV$\mathrm{T} / \mathrm{M}$ različno poimenovane tudi glede na to, ali se $\mathrm{z}$ določenim terminom želi poudariti etiološki, razvojni, fenomenološki, kurativni ali prognostični vidik (Škoflek, v Kosmač, 2007).

16 Čeprav je uporaba terminov mnogokrat sinonimna (prim. Bečaj, 2003; Kobolt idr., 2008; Kosmač, 2007; idr.), vsi zgoraj našteti termini niso sinonimni. Z njimi je namreč, kot že Zalokar (2013, str. 44), »mogoče izraziti različne fenomenološke in etiološke nianse asocialnega in antisocialnega vedenja." 
Če na tem mestu izpostavimo še trditev enega izmed referentov na mednarodnem kongresu za forenzično psihiatrijo, ki je ugotovil, »da uporabljamo po svetu za poimenovanje te skupine več kot 100 različnih poimenovanj« (Skalar, 2003, str. 10), je dejstvo, »da stroka tudi v mednarodnem prostoru v zvezi s kategorijo otrok s čustvenimi in vedenjskimi težavami ni oblikovala definicije, ki bi jo sprejeli kot splošno veljavno, kot smo jo npr. za slepe in slabovidne, gluhe in naglušne, za motorično in gibalno prizadete ali otroke $z$ duševnimi primanjkljaji« (str. 10-11), kot bo razvidno v nadaljevanju, še toliko bolj razumljivo.

\section{Razumevanje in opredeljevanje čustvenih in vedenjskih težav} in/ali motenj v polju vzgojnih zavodov

Strokovna literatura opredeljevanja in razumevanja ČVT/M, slovenskega kot tudi tujega raziskovalnega prostora, večinoma izhaja iz polja delovanja formalnega, predvsem osnovnošolskega izobraževanja ter v manjši meri iz polja delovanja VZ. Vendar pa omenjenih področij nikakor ne bi smeli enačiti.

Kljub temu, da zametki ČVT/M - s hkratnim sovplivanjem domačega, okoljskega ter vrstniškega miljeja - $\mathrm{v}$ večini izhajajo iz zaznavnega oz. diagnostičnega polja šolski ustanov, je obravnava populacije s ČVT/M v zavodski vzgoji veliko bolj kompleksa kot obravnava v osnovni šoli. Kot vemo, predstavljajo $\mathrm{VZ}$ zadnjega izmed vseh že predhodno izčrpanih arzenalov pomoči $\mathrm{v}$ domačem in $\mathrm{s}$ tem tudi šolskem okolju. Tako bi tudi uporaba terminov in definicij, ki jih za omenjeno populacijo uporabljamo, morala sovpadati s specifikami določenega strokovnega področja, iz katerega pri opredelitvah izhajamo, kar pa ne pomeni, da bi služila kakršni koli stigmatizaciji ${ }^{17}$ ter patologizirajočemu diskurzu, temveč le jasnosti opredelitev specifičnega razlagalnega področja. Ker v pričujočem delu izhajamo iz polja delovanja VZ, se pri interpretaciji spodaj opisanih terminov opiramo torej na zavodsko populacijo.

17 Sami menimo, da problem družbeno pogojene stigmatizacije ne leži toliko v terminologiji, ki se za poimenovanje določenega dela populacije uporablja, temveč le-ta izhaja iz domene, da je posameznik zaradi »drugačnosti«, ki mu jo družba pripisuje, v določeni instituciji nameščen (npr. psihiatrična bolnišnica, VZ, zapor idr.). Zato institucijo - bolj kot terminologijo - vidimo kot tisto, ki tako pri nameščenem posamezniku kot tudi pri večjem delu populacije vzbuja občutek, da je le-ta »drugačen, nezaželen in družbeno nesprejemljiv«. 
Z gledišča terminologije slovenskih avtorjev, ki se prvotno ukvarjajo $\mathrm{s}$ populacijo otrok in mladostnikov s ČVT/M, je v zadnjem desetletju zaznati zelo različno izrazoslovje povezano $\mathrm{z}$ omenjeno populacijo.

A. Kobolt (2010) v okviru raziskovalnega projekta $\mathrm{z}$ naslovom Problemi inkluzivne obravnave vedenjsko izstopajočih, socialno in kulturno depriviligiranih učencev in dijakov, katerega izsledki so izdani v monografiji Izstopajoče vedenje in pedagoški odzivi, uporablja izraz izstopajoče vedenje. Temeljno konceptualno usmeritev avtorjev omenjene monografije je, kot že Dekleva (2011), zaznati že v naslovu le-te, saj izbira pojme, ki ne implicirajo niti motnje niti težave, temveč poudarjajo interakcijsko naravo nastajanja težav. Izraz izstopajoče vedenje, kot nadaljuje Dekleva, "namreč sam po sebi ne implicira nikakršne motnje ali primanjkljaja«, s čimer avtorji v omenjeni monografiji »dosledno sledijo interakcijskemu pogledu na te težave in se praviloma uspešno izogibajo (predvsem) patologizirajočim diskurzom « (str. 199). Z napisanim se vsekakor strinjamo, predvsem kar se tiče patologizirajočega ter stigmatizirajočega diskurza, ki se ga $\mathrm{z}$ omenjenim poimenovanjem ogradimo. Vendar pa zgolj o izstopajočem vedenju $\mathrm{v}$ okviru populacije v VZ ne moremo govoriti. Čeprav ga A. Kobolt (2010) opredeli kot posledico nezmožnosti posameznikovega samoobvladovanja oz. kontrole nad lastnim vedenjem in kot nasledek notranje konfliktnosti, kar sicer nakazuje na tipične značilnosti večinskega dela zavodske populacije, pa eksplicitno ne nakaže, za kateri specifičen del populacije gre.$^{18}$ Zato menimo, da bi bilo izpostavljeni termin bolj smiselno uporabljati za populacijo otrok/mladostnikov, ki še bivajo v domačem okolju in obiskujejo »nezavodske« osnovne šole, kot za populacijo otrok/mladostnikov, ki so z odločbo centra za socialno delo (v nadaljevanju: CSD) že nameščeni v posamezni vzgojni ali vzgojno-izobraževalni zavod. Pri že nameščeni populaciji je namreč utopično govoriti le o izstopajočem vedenju, saj so predispozicije vedenjskih modalitet, ki so do namestitve pripeljale, največkrat geneza dolgotrajnejših ter večplastnih prepletajočih se kumuliranih ter manifestnih dejavnikov. Slednji se v nekaterih primerih že izražajo kot kompleksnej-

18 Prav tako lahko namreč navedeno nakazuje na skupine otrok/mladostnikov, ki niso uporabniki ne zavodskih kot tudi nobenih drugih storitev (npr. eksperimentiranje s kemičnimi substancami ipd.) in dokaj uspešno krmilijo potek svojega življenja v domačem okolju, pa je pri njih prav tako mogoče zaznati zgoraj navedene značilnosti, ki se občasno izražajo v obliki drugačnega, izstopajočega vedenja. Ker lahko termin izstopajoče vedenje zajema različne nianse neustreznih vedenj, ga sami razumemo kot splošen, širši termin z značilnostmi nedoločene konotacije, ki predstavlja enega izmed vidnih, zunanjih indikatorjev, ki botrujejo namestitvi v VZ. 
ša vedenjska težava, ki lahko nakazuje na simptome čustvene in vedenjske motnje ali (nemalokrat) kombinacijo obeh, kar pa seveda še ne pomeni, da je posameznik moten. Izstopajoče vedenje je, kot ugotavlja Kobolt (2010, str. 136), »lahko tudi bolj ali manj ciljno usmerjeno in motivirano. Torej načrtovano in ne tako kot $\mathrm{v}$ primerih impulzivnosti, ko posameznik nima zadostne kontrole nad svojimi vedenjskimi odzivi.« Prav impulzivnost in nezadostna kontrola posameznika nad svojimi vedenjskimi odzivi, ki se pri nekaterih posameznikih v VZ izražajo v silovitih eskalacijah vedenja, pa je pri populaciji nameščeni v VZ - predvsem, če pri razlagi izhajamo iz Redla in Winemana (1984) - velikokrat kazalec specifičnih kompleksnejših težav in slabe razvitosti njihovega »kontrolnega sistema", se pravi ega in superega. To pa prav tako kaže na neustreznost uporabe zgoraj omenjenega termina, predvsem $\mathrm{v}$ povezavi s populacijo nameščeno $\mathrm{v} \mathrm{VZ}$.

Vec (2011) v članku Moteče vedenje: ${ }^{19}$ ozadja in osnovni dejavniki, ki nanj vplivajo govori o motečem vedenju. Opredeli ga kot vedenje, pri katerem gre vedno za vedenje v socialni interakciji, v kar uvršča celoten spekter besedne in nebesedne komunikacije, ki se ne nanaša zgolj na agresivno vedenje, temveč na celoten »spekter vedenja, ki je socialno manj sprejemljivo oz. nesprejemljivo « (str. 126). Motečega vedenja ne enači z motnjami vedenja, temveč ga opredeli kot tisto vedenje, ki se lahko pojavi pred motnjami vedenja. Razliko med obema terminoma (s čimer se strinjamo) vidi v tem, »da če je vedenje nekoga moteče, še ne pomeni, da je (osebnostno) moten« (str. 128). Sami bi tu dodali še eno stališče, ki v povezavi z omenjenim terminom izhaja iz opredeljevanja populacije nameščene $\mathrm{v} V \mathrm{VZ}$ ter $\mathrm{z}$ njo povezanim vedenjem. Menimo namreč, da je verjetnost, da bi posameznik postal naslovnik zavodske vzgoje na podlagi tega, ker je njegove vedenje zgolj moteče, majhna. Zaradi motečega vedenja namreč v praksi še ne posežemo po tako skrajnem ukrepu, kot je oddaja v VZ, temveč poskušamo posamezniku, kolikor je le mogoče, z vsemi možnimi intervencijami pomagati najprej v domačem okolju. Je pa moteče vedenje - če k odpravljanju le-tega ne pristopimo dovolj hitro in učinkovito - lahko prediktor večjih vedenjskih odstopanj, ki v najslabšem primeru vodi do namestitve $\mathrm{v}$ VZ. Na podlagi navedenega menimo, da tudi dikcija moteče vedenje ni primerna za poimenovanje zavodske populacije. Ne glede na to, da je moteče

19 Avtor (2011) v povezavi z motečim vedenjem, v kontekstu čustvenih in vedenjskih težav, izpostavlja štiri osnovne dejavnike. In sicer: tiste, ki izhajajo iz skupine in skupinske dinamike; dejavnike, ki so povezani s posameznikom, njegovimi osebnostnimi, biološkimi in drugimi značilnostmi; dejavnike, ki izhajajo iz značilnosti in stilov vodenja, ter dejavnike, ki jih oblikuje institucija s svojo kuturo. 
vedenje vedno vedenje, ki je vezano na socialni kontekst, na socialno interakcijo in komunikacijo (str. 128) ter da imajo tudi ČVT/M srž predsipozicij svojega nastanka, prav tako vezane na socialni kontekst, socialno interakcijo ter komunikacijo, je patologija, ki smo ji v zadnjem času priča v VZ, veliko bolj kompleksna, da bi lahko bila poimenovana le s terminom mote$\check{c}$ e vedenje. Le-to, po našem mnenju, ne zajema celotnega kontinuuma koeksistence kompleksnosti teže težav populacije nameščene v VZ, hkrati pa je omenjeni izraz - enako kot že prej izraz izstopajoče vedenje - premalo natančno opredeljen. Ko govorimo o motečem vedenju, namreč ne "govorimo o specifičnem vzgojnem problemu (in specifičnem otroku, op. $a .^{20}$ ), temveč o mnogo širšem problemu, ki je tesno vpet $\mathrm{v}$ osnovne značilnosti sodobnih družb.« (Kobolt, 2010, str. 133). Na podlagi česar oba izraza, tako moteče vedenje kot izstopajoče vedenje, sami razumemo kot vedenje, ki bi ga v grobem lahko opredelili kot tisto vedenje, ki predstavlja vidne komponente značilnosti sodobnih družb in se lahko izraža tako v različnih življenjskih stilih posameznika kot tudi v oblikah »drugačnega« vedenja.

Oddelek za socialno pedagogiko znotraj socialnopedagoške stroke Pedagoške fakultete v Ljubljani, tako Š. Razpotnik (2011), uvaja in uporablja termin otroci in mladostniki s težavami v socialni integraciji, ki pa, kot že Krajnčan (2010), tudi nima enotne strokovne podpore. Izraz socialnointegracijske težave "poudari težavo, ki jo ima posameznik (saj ne zanika individualne ravni ali dimenzije), in vpelje socialno, družbeno, skupinsko, okoljsko raven, ki je $\mathrm{z}$ nastajanjem in vzdrževanjem tovrstnih težav usodno povezana.« (Metljak idr., 2010, str. 89). Na podlagi navedenega lah-

Na tem mestu velja - nanašajoč se na ključne dileme primerjav različnih teorij v razvojni psihologiji - izpostaviti še pomen ter interpretacijo individualnih razlik. Če pojasnimo: Thomas (v Batistič Zorec, 2006, str. 106) »navaja kot primer teorije, ki ne poudarja individualnih razlik, Gesellovo, ki govori predvsem o tipičnem otroku določene starosti«. Podobno tudi Piaget s teorijo povprečnega otroka (Batistič Zorec, 2006). Če torej v našem primeru izhajamo iz »teorij « zgoraj izpostavljenih vedenj, se uporabnost izpostavljenih terminov postavi pod vprašaj. In sicer, ali gre pri omenjenih terminih (moteče, izstopajoče vedenje) morebiti za »teoriji« vedenja, ki govorita predvsem o tipičnem otroku določene starosti in ne poudarjata individualnih razlik (OŠ, SŠ, VZ), ali pa se avtorja, sicer implicitno, prav tako ukvarjata $\mathrm{z}$ individualnimi razlikami specifičnega razlagalnega področja (npr. polje vzgojnih zavodov).

Thomas (v Batistič Zorec, 2006, str. 106) meni, »da želi večina teorij aplicirati svoj model na čim več otrok oziroma da govorijo o »otrocih v vseh prostorih in časih", kar pa za zgoraj navedena avtorja (Koboltovo in Veca) po vsej verjetnosti ne moremo trditi, saj oba, zaradi neposrednih izkušenj v polju zavodske vzgoje, pri svojih ugotovitvah (predvidevamo) najverjetneje implicitno izhajata tudi iz ugotovitev tega področja. 
ko rečemo, da omenjeni izraz z vpeljavo makrokomponent ter vzajemno povezanostjo oz. koeksistenco širšega družbenega okoljskega sistema opozori na različne indikatorje, ki znotraj skupine otrok ter mladostnikov s ČVT/M sicer že poudarijo večplasten problem, ki ga ta skupina zajema. Vendar pa smo sami mnenja, da je termin težave $v$ socialni integraciji širši, predvsem pa krovni termin, ki pomanjkljivo opredeli ter oriše specifike populacije nameščene v VZ. Podobno je s kategorijo "posebne potrebe «, ki poleg otrok/mladostnikov z disocialno simptomatiko vključuje še vrsto drugih (Bečaj, 2003). Strinjamo se z Bečajem, ki pravi, da imajo otroci z disocialno simptomatiko

"praviloma res težave $z$ vključevanjem $v$ socialno okolje, vendar pa to ni zgolj njihova posebnost (prim. Kosmač, 2007). Enake težave ima še kup drugih otrok, ki z vedenjsko problematiko nimajo nobene povezave (npr. izjemno nadarjeni). Tudi tu je torej potrebno vsakič še dodatno pojasniti, za kateri del populacije, ki ima težave $z$ $v k l j u c ̌ e v a n j e m$ v socialno okolje, gre. Oba termina sta nadredna in sama po sebi še ne označujeta kategorije otrok, o kateri govorimo. Oba sta sicer točna, za diagnostiko pa, tako kot termini, ki so vezani na simptomatiko, slabo uporabna." (str. 14)

Pomanjkljivosti, ki jih vidimo v omenjenem poimenovanju, temeljijo, poleg že navedenega, še v kompleksnosti, izraznosti ter pojavnosti težav, ki jih je pri določenem delu zavodske populacije zaznati in se kažejo v obliki Bregantove (1987a) fenomenološke klasifikacije, kar pa iz omenjenega termina zaradi nezadostne specifičnosti ni mogoče razbrati.

Poleg termina težave $v$ socialni integraciji se $\mathrm{v}$ slovenskem strokovno-raziskovalnem ter praktičnem prostoru za opredeljevanje populacije nameščene v VZ kot najpogosteje uporabljeni termini pojavljajo še: čustvene in vedenjske težave, čustvene in vedenjske motnje (prim. Kobolt idr., 2008) ali največkrat kombinacija obeh: čustvene in vedenjske težave/motnje.

21 V kategorijo OPP po ZUOPP-1 (2011) spadajo: otroci z motnjami v duševnem razvoju, gluhi in naglušni otroci, slepi in slabovidni otroci, otroci z govorno-jezikovnimi motnjami, gibalno ovirani otroci, otroci s primanjkljaji na posameznih področjih učenja, dolgotrajno bolni otroci, otroci s čustvenimi in vedenjskimi motnjami, otroci $z$ avtističnimi motnjami.

Termin »otroci s posebnimi potrebami« so v 7o. letih vpeljali Angleži (Skalar, 2003). Le-ta naj bi bil manj stigmatizirajoč, kot je npr. razvojno prizadet ali defekten, toda prav "Angleži danes odsvetujejo termin "posebne potrebe", češ da je prav tako stigmatizirajoč, kot so bili vsi drugi doslej.« (Mittler, v Skalar, 2003, str. 13). 
Poskušajmo opredeliti še razliko med razumevanjem težave in motnje. Metljak idr. (2010, str. 89) pravijo, da gre za težavo takrat, ko lahko rečemo, da "nek način čustvovanja ali vedenjskega odziva ne moti niti posameznikovega razvoja niti ni izrecno moteč za okolico«. Motnjo opredelijo kot problem posameznika in problem okolja, saj predstavlja resno oviro za njegov psihosocialni in osebnostni razvoj, hkrati pa je moteča tudi za okolje (Metljak, 2010, str. 89). Vendar pa, če pri interpretaciji zgoraj izpostavljenih terminov izhajamo iz zavodske populacije, so otroci/mladostniki v VZ (predvsem zavodih zaprtega tipa) ponavadi nameščeni ravno zato, ker je nek način čustvovanja in vedenjskega odziva motil ali posameznikov razvoj in/ali je bil moteč za okolico. Na podlagi česar bi, izhajajoč iz zgoraj navedene opredelitve obeh terminov, lahko sklepali, da pri že nameščeni populaciji ne moremo govoriti izključno o težavah, temveč tudi o motnjah, saj je ravno podana opredelitev termina motnja tisti dejavnik, ki do namestitve v praksi pripelje. Če misel razvijamo še naprej, Metljak idr. (2010, str. 89) za težave pravijo:

"Težave so lahko prehodne in z njimi se lahko posameznik kot tudi okolje precej dobro spoprime in jih obvlada. Težave so del vsakodnevnega življenja slehernega od nas. S težavo/težavami, bodisi socialnimi bodisi emocionalnimi, materialnimi, odnosnimi in drugimi, se ljudje bolje spoprimemo, če imamo podporo ožjega in širšega socialnega okolja in če najdemo dovolj primernih virov za spoprijemanje. Če okolje daje to podporo in je do potreb posameznika pozorno, se občasne težave dobro rešujejo že s pogovorom, spremembami posameznih odnosov ali elementov situacije."

Iz podane opredelitve lahko razberemo, da gre za splošen opis težav, ki ne ustreza opredelitvam težav populacije $\mathrm{v} V \mathrm{VZ}$, temveč so podane opredelitve diametralne tistim, ki do namestitve pripeljejo. Za populacijo $\mathrm{v} V Z$ je namreč značilno, da njihovih težav ne moremo opredeliti več kot predhodne, saj so se v različnih oblikah intervencij praviloma poskušale odpraviti že v posameznikovem primarnem okolju (pred namestitvijo v VZ), vključujoč različne mreže pomoči podpornih dejavnikov ožjega in širšega socialnega okolja; da se posameznik s svojimi težavami ne zna ustrezno spopadati, prav tako pa se z njimi praviloma ne zna (ali pa se ni zmožno) spopadati njegovo primarno okolje. Iz tega sledi, da jim praviloma primanjkuje podpore ožjega in širšega socialnega okolja oz. primernih ter ustreznih virov za spoprijemanje $\mathrm{z}$ različnimi vrstami težav, kar pa je med drugim tudi razlog, zaradi česar so ti posamezniki postali naslovniki zavodske vzgoje. 
Izpostaviti velja še naslednji pomislek v zvezi s poimenovanjem omenjene populacije, in sicer da je vedenje, kot vemo, interakcijsko pogojeno predvsem z okoljem posameznika. ${ }^{22}$ Vendar pa noben obstoječi termin za poimenovanje populacije $\mathrm{s}$ ČVT/M ne zajema vidika vedenja $\mathrm{v}$ taki meri, da bi bilo razvidno, da so bistvo neprimernega oz. drugačnega vedenja dolgotrajne posledice različnih kompleksnih težav $\mathrm{v}$ otrokovem/mladostnikovem okolju in ne v njem.

Če se vrnemo k terminologiji. Termin »otroci in mladostniki s čustvenimi in vedenjskimi težavami oz. motnjami«, tako Bečaj (2003), se vsaj na prvi pogled zdi bolj ustrezen. Vendar pa tudi pri tej opredelitvi obstajajo določene težave. Vemo, kot v nadaljevanju ugotavlja avtor, da obstajajo otroci/mladostniki, ki so čustveno moteni, niso pa disocialni, in taki, ki kažejo disocialno simptomatiko, niso pa čustveno moteni. Oznaka »čustvene in vedenjske motnje « torej velja la za tiste otroke/mladostnike, pri katerih najdemo oboje, kar pa izhajajoč iz ugotovitev Bečaja ${ }^{23}$ (2003) - pri čemer izhaja iz Bregantove klasifikacije - pomeni isto kot »motnje vedenja in osebnosti«, saj ta diagnoza poleg disocialne simptomatike že vključuje tudi čustvene motnje. Termin »otroci in mladostniki s čustvenimi in vedenjskimi težavami oz. motnjami«, kot pravi Bečaj, »ni tak, ker ni del sistematično kategoriziranih disocialnih motenj.«

Kontinuum razumevanja razvoja variabilnosti vedenja od težave do motnje, kot poimenovanja specifične skupine posameznikov, tako sovpada tudi z uporabo klasifikacije, iz katere pri razlagi omenjenega fenomena izhajamo. ${ }^{24}$

22 Na žalost (nemalokrat) iz tega med drugim izhaja tudi naša strokovna nezadostnost oz. (ne)pomoč, ki je posameznikom opredeljenim kot otroci/mladostniki s ČVT/M na voljo. Predvsem pri populaciji nameščeni v VZ se navedeno pokaže kot upravičeno, saj se otrokovo/mladostnikovo primarno okolje s prihodom le-tega v VZ ponavadi ne spremeni, temveč ostaja isto. Pri posamezniku je tako v zavodskem okolju sicer zaznati izboljšave njegovih neprimernih vzorcev vedenja, vendar se taisti posameznik med vikendi vrača $v$ domače (še vedno) disfunkcionalno okolje, ki v večini primerov ostaja isto, kot je bilo pred namestitvijo otroka/mladostnika v zavodsko institucijo.

23 Bistveno razliko med obema oznakama Bečaj vidi v tem, »da so »motnje vedenja in osebnosti« ena od kategorij Bregantove klasifikacije, ki pri diagnosticiranju seveda izključuje ostale kategorije in obratno: uporaba neke druge kategorije izključuje motnje vedenja in osebnosti. Informacijska vrednost take diagnostične ocene je seveda veliko večja, ker je del širše klasifikacijske sheme in s tem že sama po sebi diferencialna." (Bečaj, 2003, str. 14).

24 Vendar pa se sami na tem mestu ograjujemo od klasifikacij in se sprašujemo le o ustreznosti termina, ki bi ga bilo za poimenovanje zavodske populacije najbolj smiselno uporabljati. 
Opozoriti velja, da celotne populacije v VZ nikakor ne moremo opredeliti kot populacije $s$ »čustvenimi in vedenjskimi težavami«, prav tako pa celotne zavodske populacije ne moremo opredeliti kot populacije $s$ »čustvenimi in vedenjskimi motnjami«. Prvič zaradi tega, ker vemo, da v določenem časovnem obdobju ${ }^{25}$ (puberteti), nenadni ter predvsem neugodni življenjski situaciji, pa tudi ob stiku z določenimi osebami, lahko postane »težaven « vsak posameznik, ki na tak ali drugačen način kaže kakršno koli vedenjsko odstopanje ter ne zadovoljuje pričakovanj vedenjskih modalitet določene kulture (Bečaj, 2003; Skalar, 2003; Tomori, 1999), kar v enaki meri velja tako za nezavodsko kot tudi zavodsko populacijo. Ter drugič, ker v VZ (kot že rečeno) najdemo posameznike, ki so čustveno "moteni«, niso pa disocialni, in take, ki kažejo disocialno simptomatiko, niso pa čustveno »moteni«. Pri nekaterih je tako zaznati izrazitejše internalizirane oblike izražanja, stiske, anksioznosti in nemoči, pri drugih eksternalizirane oblike izražanja, jeze in agresije, pri tretjih kombinacijo obeh.

$\mathrm{Na}$ tem mestu velja izpostaviti še en vidik, ki se nanaša na težavnost enotnega poimenovanja populacije nameščene $\mathrm{v} \mathrm{VZ}$. Ta je, da tudi znotraj izvendružinskega institucionalnega aparata opredeljevanja, razumevanja ter interpretiranja ČVT/M - se pravi VZ, mladinskih domov ter stanovanjskih skupin - obstajajo razlike. Kljub temu, da vse zgoraj naštete institucije obravnavajo populacijo, katere značilnosti bi v grobem sicer lahko opredelili kot identične, pa $\mathrm{v}$ praksi temu ni tako. Mladinski domovi in stanovanjske skupine (že na podlagi svoje namembnosti) sprejemajo populacijo, ki se od populacije v VZ praviloma razlikuje po večji meri samostojnosti, odgovornosti ter upoštevanju pravil oz. manjši, predvsem »vedenjsko izstopajoči« problematiki, zato bi tudi tu bilo potrebno upoštevati specifike dotičnega raziskovalnega področja, iz katerih pri opredelitvah izhajamo, kar pa fenomen poimenovanja, jasnost ter ustreznost le-tega še dodatno oteži. 


\section{Sklep}

Zaključujemo, da je obravnavano področje - tudi znotraj zavodske vzgoje - zelo kompleksno, kriteriji izpostavljenih terminov nejasni in premalo opredeljeni, predvsem pa odvisni od kombinacije oz. interakcije več heterogenih dejavnikov, ki svojo pravo težo pri vsakem konkretnem otroku/ mladostniku dobijo šele $\mathrm{v}$ specifični kombinaciji, zaradi česar postane tudi uporaba terminologije precej relativna (prim. Bečaj, 2003).

Strinjamo se z Bečajem (str. 13), ki pravi, da je prehitro uvrščanje otroka/mladostnika »v kategorijo osebnostno motenega, samo zaradi prisotne simptomatike «, lahko nevarna. Zato se - kljub temu, »da se nekatera omenjena stanja in vzorci vedenja kažejo že zgodaj v otroštvu « (ZUOPP-1, 2011) - tudi sami ograjujemo od poimenovanja oz. diagnoze »osebnostne motnje«, saj se le-ta »ne postavlja, vse dokler ni zaključen otrokov osebnostni razvoj.«

Smo pa enotnega mnenja z Bečajem (2003) tudi, ko pravi, da je težava s terminologijo, ki se poskuša izogniti slabšalnemu označevanju, »v tem, da prav zaradi tega ostaja ponavadi na zelo splošni ravni, tako da nam uporabljani izrazi ne povedo, za kaj pravzaprav gre« (str. 14) oz. na katero specifično kategorijo posameznikov se določeno poimenovanje nanaša.

Na podlagi navedenega in ker je (kot že rečeno) pri zavodski populaciji zaznati kontinuum več, predvsem pa različnih nians med seboj prepletenih neustreznih vedenj, ki se lahko - odvisno od posameznika, njegovega socialnega okolja ter celotnega življenjskega mikro, mezo, eko in makro sistema - izražajo kot internalizirane oblike, eksternalizirane oblike ali kombinacija obeh, sami za poimenovanje zavodske populacije (predvsem tiste, nameščene v klasičnih oblikah zavodske vzgoje oz. zavodih »zaprtega" tipa) uporabljamo termin "čustvene in vedenjske težave in/ali motnje«, ${ }^{26}$ kar pa nikakor ne pomeni, da čustvene in vedenjske motnje enačimo $\mathrm{z}$

26 Da gre pri že nameščenem otroku/mladostniku za ČVT/M, morajo biti prisotni naslednji kriteriji (Kobolt, 2011; Bregant, 1987b):

- da gre za »neobičajno«, precej drugačno vedenje od povprečnega;

- da se čustvena in/ali vedenjska slika pojavlja intenzivno, skozi daljše časovno obdobje;

- da je vedenjski in/ali čustveni problem resen ter da obstaja nevarnost za njegov nadaljnji razvoj;

- da le-ta ogroža posameznikov razvoj in/ali je zaradi njegovega vedenja »ogrožena« okolica;

- da je z običajnimi ter razpoložljivimi intervencijami v primarnem okolju nismo uspeli ublažiti oz. odpraviti do te mere, da bi lahko bil posameznikov psihosocialni razvoj v domačem okolju optimalen. 
osebnostnimi motnjami, temveč se skušamo z omenjenim poimenovanjem le približati kompleksnim značilnostim zavodske populacije.

Zavedamo se, da tudi to poimenovanje populacije $\mathrm{v} V \mathrm{VZ}$ ni popolnoma ustrezno, da le-to še vedno izraža sled posplošitev ter da, kot že Metljak idr. (2010, str. 93), še vedno »ostaja kategorialna nalepka, ki ne odraža enkratnosti in posameznih, lahko zelo raznolikih značilnosti tako posameznika kot njegove socialne umeščenosti«. Vendar pa na podlagi dolgoletnega neposrednega dela $\mathrm{z}$ zavodsko populacijo menimo, da omenjeni izraz, s hkratnim zajetjem težave in/ali motnje, v dovolj veliki meri opozori na kompleksne značilnosti, ki jih je pri populaciji nameščeni v VZ zaznati. Z veznikom in/ali nakažemo, da lahko gre ali za težavo ali za motnjo ali pa sta prisotni obe obliki oz. komponenti vedenja.

\section{Literatura}

Batistič Zorec, M. (2006). Teorije v razvojni psihologiji. Ljubljana: Univerza v Ljubljani, Pedagoška fakulteta.

Bečaj, J. (1987). L. Bregant: Disocialnost pri otrocih in mladostnikih. Psihoterapija, 15, 9-70.

Bečaj, J. (2003). Disocialnost pri otrocih in mladostnikih. Slovenska pediatrija, 10(1), 12-27.

Bela knjiga o vzgoji in izobraževanju v Republiki Sloveniji (2011). J. Krek in M. Metljak (ur.). Ljubljana: Ministrstvo za šolstvo in šport.

Bregant, L. (1987a). Navodilo za klasifikacijo disocialnih motenj. Ptički brez gnezda, 12(25), 7-21.

Bregant, L. (1987b). Diagnostično vrednotenje in prognostična ocena disocialnih motenj. Ptički brez gnezda, 12(25), 23-27.

Byrne, Š. (2010). Sistemski pogled na vedenjske težave pri osebah z motnjami v duševnem razvoju. V V. Bužan, A. Golob, Š. Byrne in B. Hegedüš (ur.), Težave v vedenju kot izziv: Naša pot (str. 32-36). Ig: CUDV Draga.

Dekleva, B. (2011). Prikaz knjige - Alenka Kobolt (ur.): Izstopajoče vedenje in pedagoški odzivi. V O. Poljšak Škraban (ur.), Razumevanje in odzivanje na problematiko otrok s težavami v socialni integraciji (str. 197-200). Socialna pedagogika, tematska številka, 15(2).

Evans, J., Harden, A., in Thomas, J. (2004). What are effective strategies to support pupils with emotional and behavioral difficulties (EBD) in mainstream primary schools? Findings from a systematic review of research. Journal of Research in Special Education Needs. 4(1), 2-16. 
Kenneth, K., Forness, S., in Mostert, M. (2004). Defining emotional or behavioral disorders: The quest for affirmation. V P. Clough, P. Garner, J. T. Pardeck in F. Yuen (ur)., Handbook of emotional \& behavioral difficulties (str. 45-58). Thousand Oaks, CA: SAGE Publications.

Kobal Tomc, B., Centrih, M., Zalokar, L., Švab, V., Bužan, V., Klanjšček, M., in Pavlič, S. (2011). Otroci in mladostniki s hudimi motnjami vedenja Analiza stanja. Ljubljana: Inštitut Republike Slovenije za socialno varstvo.

Kobolt, A. (2010). Oblike in pogostost motečega vedenja ter razlogi, ki jih učitelji pripisujejo takemu vedenju. V A. Kobolt (ur.), Izstopajoče vedenje in pedagoški odzivi (str. 115-164). Ljubljana: Pedagoška fakulteta.

Kobolt, A. (2011). Razumevanje in odzivanje na čustvene in vedenjske težave. V O. Poljšak Škraban (ur.), Razumevanje in odzivanje na problematiko otrok s težavami v socialni integraciji (str. 153-173). Socialna pedagogika, tematska številka, 15(2).

Kobolt, A., Metljak, U., in Potočnik, Š. (2008). Zadrege z definicijami - pot $\mathrm{k}$ drugačnemu razumevanju izstopajočega vedenja. V A. Kobolt (ur.), Problemi inkluzivne obravnave vedenjsko izstopajočih, socialno in kulturno depriviligiranih učencev in dijakov (str. 48-59). Univerza v Ljubljani: Pedagoška fakulteta.

Krajnčan, M. (2006). Na pragu novega doma: Oddaja otrok v vzgojni zavod. Ljubljana: Pedagoška fakulteta.

Krajnčan, M. (2010). Otroci in mladostniki v vzgojnih zavodih, stanovanjskih skupinah in mladinskih domovih. V M. Krajnčan in P. Miklavžin (ur.), Zdravje mladostnikov s čustvenimi in vedenjskimi težavami (str. 34-55). Ljubljana: Ministrstvo za zdravje.

Krajnčan, M., in Škoflek, I. (200o). Pregled nekaterih klasifikacij motenj vedenja in osebnosti otrok in mladostnikov. Socialna pedagogika, 4(2), 167-180.

Kriteriji za opredelitev vrste in stopnje primanjkljajev, ovir oz. motenj otrok s posebnimi potrebami (2. izdaja) (2015). N. Vovk Ornik (ur.). 2. izdaja. Ljubljana: Zavod RS za šolstvo.

Kosmač, S. (2007). (Ne)ustreznost kriterijev za opredeljevanje otrok s čustveni$\mathrm{mi}$ in vedenjskimi motnjami. Socialna pedagogika, 11(3), 361-383.

Marovič, M. (2017). Participacija otroka/mladostnika v vzgojnih zavodih (Doktorska disertacija). Univerza na Primorskem, Pedagoška fakulteta, Koper.

Metljak, U., Kobolt, A., in Potočnik, Š. (2010). Narava čustvenih, vedenjskih in socialnih težav se izmika definicijam. V A. Kobolt (ur.), Izstopajoče 
vedenje in pedagoški odzivi (str. 87-113). Ljubljana: Pedagoška fakulteta Univerze v Ljubljani.

Myschker, N. (2009). Verhaltensstörungen bei Kindern und Jugendlichen: Erscheinungsformen - Ursachen - Hilfreiche Maßnahmen. Stuttgart: W. Kohlhammer Druckerei.

MKB-10 (2005). Mednarodna klasifikacija bolezni in sorodnih zdravstvenih problemov za statistične namene. Deseta revizija, 1. knjiga (2. izdaja). Ljubljana: Inštitut za varovanje zdravja Republike Slovenije.

Opara, B., Barle, A., Globačnik, B., Kobal Grum, D., Košir, S., Macedoni Lukšič, M., ... Vršnik Perše, T. (2010). Analiza vzgoje in izobraževanja otrok s posebnimi potrebami. Ljubljana: Pedagoški inštitut.

Razpotnik, Š. (2011). Družbeni kontekst kategorije »čustvene in vedenjske motnje«. V O. Poljšak Škraban (ur.), Razumevanje in odzivanje na problematiko otrok s težavami v socialni integraciji (str. 103-123). Socialna pedagogi$k a$, tematska številka, 15(2).

Redl, F., in Wineman, D. (1984). Agresiven otrok: povzetek. Ljubljana: Svetovalni center v Ljubljani, Sekcija za skupinsko delo in osebnostno rast Društva psihologov Slovenije.

Skalar, V. (2003). Socialna integracija otrok $\mathrm{z}$ vedenjskimi in čustvenimi težavami v osnovni šoli. Šolsko svetovalno delo, 3-4(8), 8-14.

Svetin Jakopič, S. (2005). Obravnava otrok in mladostnikov z vedenjskimi motnjami na centru za socialno delo: Pomoč ali prisila. Socialna pedagogika, 9(4), 391-422.

Tomori, M. (1999). Duševne motnje v razvojnem obdobju. V M. Tomori in S. Ziherl (ur.), Psihiatrija (str. 317-351). Ljubljana: Medicinska fakulteta.

Vec, T. (2011). Moteče vedenje: ozadja in osnovni dejavniki, ki nanj vplivajo. V O. Poljšak Škraban (ur.), Razumevanje in odzivanje na problematiko otrok s težavami v socialni integraciji (str. 125-152). Socialna pedagogika, tematska številka, 15(2).

Zalokar, L. (2013). Evalvacija institucionalnega obravnavanja mladinske odklonskosti - primer Vzgojnega zavoda Planina (Doktorska disertacija). Univerza v Ljubljani, Pedagoška fakulteta, Ljubljana.

Zakon o usmerjanju otrok s posebnimi potrebami (ZUOPP-1) (2011). Uradni list RS, št. 58/2011 z dne 22. 7. 2011. Pridobljeno s http://www.zrss.si/ pdf/o50911123118_zakon_o_usmerjanju_otrok_s_posebnimi_potrebami_22072011.pdf 
Zorc Maver, D. (2010). Nekateri vidiki zdravja otrok in mladostnikov. V M. Krajnčan in P. Miklavžin (ur.), Zdravje mladostnikov s čustvenimi in vedenjskimi težavami (str. 24-31). Ljubljana: Ministrstvo za zdravje. 